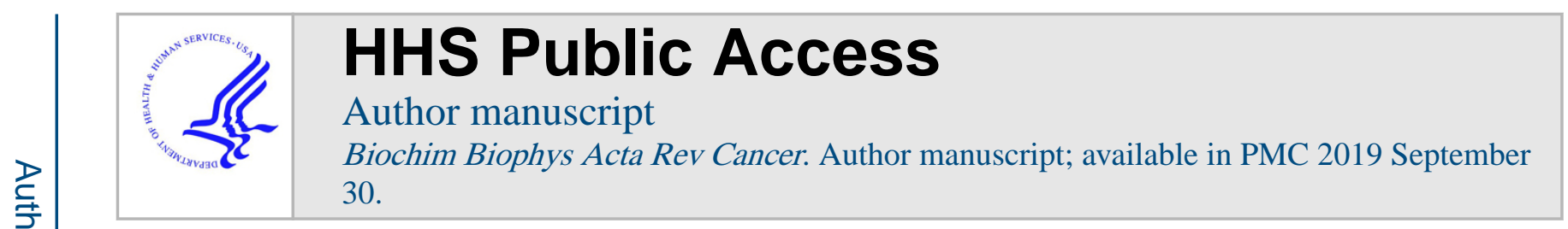

Published in final edited form as:

Biochim Biophys Acta Rev Cancer. 2017 December ; 1868(2): 500-509. doi:10.1016/j.bbcan. 2017.09.005.

\title{
The role of nitric oxide in melanoma
}

\author{
Keerthi Yarlagadda, John Hassani, Isaac P. Foote, Joseph Markowitz \\ Department of Cutaneous Oncology, Moffitt Cancer Center Tampa, FL 33612
}

\begin{abstract}
Nitric oxide (NO) is a small gaseous signaling molecule that mediates its effects in melanoma through free radical formation and enzymatic processes. Investigations have demonstrated multiple roles for NO in melanoma pathology via immune surveillance, apoptosis, angiogenesis, melanogenesis, and on the melanoma cell itself. In general, elevated levels of NO prognosticate a poor outcome for melanoma patients. However, there are processes where the relative concentration of NO in different environments may also serve to limit melanoma proliferation. This review serves to outline the roles of NO in melanoma development and proliferation. As demonstrated by multiple in vivo murine models and observations from human tissue, NO may promote melanoma formation and proliferation through its interaction via inhibitory immune cells, inhibition of apoptosis, stimulation of pro-tumorigenic cytokines, activation of tumor associated macrophages, alteration of angiogenic processes, and stimulation of melanoma formation itself.
\end{abstract}

\section{Keywords \\ nitric oxide; melanoma}

\section{Mechanisms of nitric oxide production in melanoma}

Nitric oxide (NO) is a free radical inorganic signaling molecule that is generated via multiple mechanisms (Figure 1). One of these mechanisms catalyzed by nitric oxide synthase (NOS) is the oxidation reaction of L-arginine and oxygen with a NADPH cosubstrate to produce L-citrulline and NO [1]. There are 3 isotypes of NOS in humans: neuronal NOS (nNOS or NOS1), inducible NOS (iNOS or NOS2) and endothelial NOS (eNOS or NOS3). iNOS is transcriptionally induced by immunologic stimuli produced by various cells in the immune system (e.g. macrophages) in a calcium independent manner [2, 3]. The eNOS and nNOS isoforms have been collectively grouped as constitutively active NOS (cNOS). These cNOS isoforms are constitutively expressed and their activity has classically been thought to be dependent on prior calcium influx that enables the isoforms to bind to calmodulin. Normal melanocytes express both cNOS and iNOS [4].

Corresponding Author: Joseph Markowitz, M.D., Ph.D., Assistant Member, Department of Cutaneous Oncology, Moffitt Cancer Center, Tampa, FL 33612, joseph.markowitz@ moffitt.org, Phone: (813) 745-3437.

Conflicts of interest

The authors declare that they have no conflicts of interest. 
Another source of NO is the conversion of nitrate into NO in a two-step process. First nitrate is reduced to nitrite and then nitrite is reduced to nitric oxide. For example, oral bacteria reduce dietary inorganic nitrate into nitrite and then in an acidic environment such as the stomach nitrite is then reduced to NO via non-enzymatic disproportionation [5-7]. Therefore, it is not surprising that the major sources of nitrate and nitrite are the diet, products of the endogenous NOS pathway, and products of the oxidation and reduction by commensal organisms $[1,7]$. A similar mechanism occurs in the skin where nitrate present in the sweat is reduced to nitrite with subsequent conversion to NO in the presence of the acidic skin surface [8]. Nitrite may also be converted into NO enzymatically via the xanthine oxidoreductase or proteins containing the iron porphyrin moiety (e.g. cytochrome c, deoxyhemoglobin, mitochondrial electron transport chain) [2, 9]. In normal human skin, photolabile compounds (e.g. nitrate, nitrite and the S-nitroso compounds such as Snitrosothiols, S-nitrosoalbumin, S-nitrosoglutathione or S-nitrosocysteine) generated NO via photodecomposition after exposure to ultraviolet A (UVA) or blue light. In the presence of blue light, photolabile NO derivatives photodecompose to $\mathrm{NO}$ via a copper $\left(\mathrm{Cu}^{1+}\right)$ dependent mechanism. In the presence of UVA radiation, nitrite decomposed to NO and subsequent electron transfer reactions generated highly toxic nitrogen dioxide $\left(\mathrm{NO}_{2}{ }^{\circ}\right)$, which in turn initiated a lipid peroxidation chain reaction $[10,11]$. It is not surprising with these interdependent processes nitrite can also serve as the substrate to form s-nitrosothiols in vivo [12]. NO and metabolites of NO such as nitrite may be measured via colorimetric dyes such as the Griess reagent, fluorescent dyes such as DAF-FM, and in vivo via electron paramagnetic resonance spectroscopy [13-15]. Generally, NO may be derived enzymatically (NOS, xanthine oxidoreductase, or iron porphyrin containing proteins) or non-enzymatically (UVA or blue light photochemistry or low $\mathrm{pH}$ induced disproportionation).

\section{Nitric Oxide Biochemistry}

NO exerts its effects through two major signaling pathways, the cGMP dependent pathway and the cGMP independent pathway (Figure 2) [16]. In the cGMP dependent pathway, NO synthesized from NOS diffuses across the plasma membrane and cytoplasm, reacts with the active site of soluble guanylate cyclase and produces cGMP. cGMP then phosphorylates the cGMP dependent protein kinase $\mathrm{G}$, which in-turn phosphorylates and activates cGMP dependent gated ion channels and phosphodiesterase. As describes above, NO and its derivatives may be involved in redox chemistry with other small molecules and metal complexes on proteins $[6,17]$. The cGMP independent pathway occurs commonly through modification of proteins through S-nitrosylation of cysteine residues $[16,18]$. Nitrosation or nitrosylation (biological term for nitrosation) is the incorporation of NO onto another molecule with an alkene bond between the $\mathrm{N}$ and $\mathrm{O}$. Such post translational modifications affect transcriptional activity by alteration of DNA-protein interactions $[16,19]$.

The derivatives of NO are responsible for multiple post-translational modifications resulting in altered functional properties of proteins [2]. NO can react with superoxide anions to yield peroxynitrite, which in turn serves as a nitrating and nitrosylating agent. Peroxynitrite interacts with amino acids, generating nitrotyrosine and reversible thiol nitrosylation [20]. In fact, there are known motifs in proteins that have been shown to be preferentially nitrosylated [18]. A literature review of 233 S-nitrosylated proteins revealed that S- 
nitrosylation sites were found in alpha helices, solvent accessible areas, and structural motifs with charged amino acids within 6 angstroms [21]. S-nitrosylated proteins are also involved in the reactions of energy metabolism such as mitochondrial respiration/proliferation and reactions of glucose metabolism [21, 22]. To review, researchers have divided Snitrosylation mechanisms into NOS dependent and independent pathways [23]. NO itself can diffuse intracellularly and bind to a heme moiety of guanylate cyclase. This event leads to enzymatic activation and subsequent formation of cyclic GMP and signaling via the MAPK cascade and JAK/STAT pathway [24]. Nitration is the incorporation of the $\mathrm{NO}_{2}$ moiety via peroxynitrite intermediates most often on tyrosine residues. It is likely that peroxynitrite binds to carbon dioxide and this nitrosoperoxycarbonate radical then reacts with tyrosine residues to form 3-nitrotyrosine [17]. Like protein nitrosylation, common motifs for nitration have been identified and there is a computational prediction program known as GPS-YNO2 to predict tyrosine nitration sites on proteins [25]. Other protein residues such as phenylalanine have been nitrated in vitro [26]. According to the described literature, protein nitration is considered to be an irreversible event, and nitrosylation is considered to be reversible. In general NO can be thought of as acting on biological pathways via small molecule and protein interactions [6, 17, 19, 27].

Nitric oxide biochemistry was initially thought to be non-enzymatic in character. However, nitric oxide derivatives may bind to iron complexes to facilitate nitration at a later time. NO can be transported by hemoglobin to sites of low oxygen concentrations (e.g. rapidly growing tumors), and then can release NO to competitively inhibit proteins such as cytochrome $\mathrm{c}$ that also contain iron complexes [28]. Cytochrome $\mathrm{c}$ can both transport NO and itself be nitrated to mediate apoptosis of T cells [29]. Other metalloproteins besides cytochrome c containing ferric iron, iron sulphur clusters, copper or zinc ion structural motifs may also be the targets for NO [22]. NO biological effects can therefore be divided into whether they are dependent on transient elevations in nitric oxide concentrations (eNOS and nNOS) dependent on calcium fluxes within the cell, or more sustained elevations in nitric oxide levels (iNOS) [24]. From the above description of NO biochemistry, it is clear that NO may play roles in the immune system, cell death, and cell proliferation. This paper describes the roles of $\mathrm{NO}$ within the context of melanoma.

\section{Sources of nitric oxide in melanoma}

Historically, iNOS was found to be overexpressed by macrophages, but NO produced by iNOS was found to be important in the proliferation in melanoma cell lines such as A375, WM94, YU SAC2, and YUZAZ6 [30, 31]. iNOS expression is higher in melanoma cells than normal melanocytes and the expression level increased with increased Clark stage of melanoma [32,33]. This is significant as increasing Clark stage represents an increased thickness of the melanoma and is associated with an increased risk of metastasis [34]. Interestingly, the expression of iNOS in melanoma tumor specimens can range from completely negative to nearly $100 \%$ positive in all cells [30]. This finding of increased iNOS expression is not limited to cutaneous melanoma. In other subsets of melanoma such as choroidal melanoma there is increased expression of iNOS activity in melanoma cells compared to melanocytic nevi [35]. Cutaneous melanoma lesions expressed iNOS within the papillary dermis and in the walls of blood vessels [32]. While, in metastatic lesions, iNOS 
expression was more intensely stained in neoplastic cells at the periphery of the tumor mass than the center $[32,33]$. Whereas, in lymph nodes with confirmed metastasis, the NO staining was greater in the marginal sinus than the lymphoid parenchyma [32]. From this study we can conclude that the expression of iNOS is involved in the early steps of the conversion from a melanoma contained within the skin to a metastatic lesion [32]. In cutaneous melanoma samples from patients, iNOS expression was also found to be high in basal and suprabasal epidermal layers, adnexal epithelium, and in macrophages. In some cases endothelial cells expressed iNOS, notably in areas of regression of melanoma and within the cytosol of presumed melanoma cells within the tissue sections [33]. Interestingly, there is an association between density of iNOS staining and higher lymphatic vessel density in melanoma samples [33]. The aforementioned investigations described the role of iNOS expression in melanoma, but nNOS protein has also been studied in melanoma cells. In one such study, $49 \%$ of benign nevi, $72 \%$ of atypical nevi, and $82 \%$ of primary malignant melanoma expressed nNOS [36]. Furthermore, an inhibitor of nNOS utilized in melanoma cell lines resulted in decreased intracellular levels of $\mathrm{NO}$ and reduced proliferation of melanoma cells [37]. It has been observed that NO can be produced by the melanoma tumor cells by themselves or by cells in the tumor environment. In BRAF mutant A375 melanoma cell lines have low production of NO production at baseline. In this case, NO diffuses from macrophages and other immune cells to exert its effects on the tumor cells [38]. Interestingly, in the tumor microenvironment, high levels of NO exert cytotoxic effects whereas low levels of NO promote tumor growth [16]. Therefore, the notion has been introduced that nitric oxide has both pro-tumorigenic and anti-tumorigenic roles [39]. A discussion of the role of $\mathrm{NO}$ in the immune system, apoptosis (and general cellular cytoxicity) of melanoma cells, initiation of melanoma growth, angiogenesis, development of metastases, and thoughts for potential therapeutic interventions in melanoma is the subject of this review of nitric oxide in melanoma.

\section{Production of NO by tumor associated macrophages is increased by melanoma cells}

NO influences the inflammatory microenvironment of melanoma to facilitate tumor cells escape from the immune system. For example, human ulcerated melanomas that are prone to worse patient outcomes demonstrated significantly higher percentage of intratumoral iNOSpositive tumor associated macrophages (TAMs) in comparison to melanomas that were found to be nonulcerated [40]. Murine melanoma tumor cells directly stimulated macrophages to release NO by cell to cell interaction via IFN- $\gamma$ dependent pathways [40, 41]. Although first observed in a lung cancer murine model, another possible mechanism by which NO mediated tumor growth is inhibition of the IL-12 tumor regressing cytokine by macrophages and subsequent growth of melanoma in murine models [42, 43]. DC-derived macrophages may also utilize $\mathrm{NO}$ to inhibit $\mathrm{CD} 8^{+} \mathrm{T}$ cell proliferation and facilitate immune escape [44]. Synthetically, the triterpenoid, CDDO-Imidazolide inhibits NO production by iNOS in murine macrophages and inhibits B16 murine melanoma growth [45]. Interestingly, $\mathrm{NO}$ can also mediate melanoma tumor regression in certain circumstances. Immune cells such as NK cells may facilitate production of high levels of production of NO by macrophages to kill B16 melanoma cells [46]. In addition cytotoxic T cells are recruited to the melanoma cells (MeWo) after low dose radiation by iNOS ${ }^{+}$macrophages [47]. There are 
clearly scenarios where macrophages are responsible for increased or decreased NO concentration through the actions of macrophages.

\section{Myeloid Derived Suppressor Cells (MDSCs) promote immune suppression via NO dependent mechanisms}

MDSCs are a class of immature myeloid cells that are typically subdivided into monocytic (M-MDSC) and granulocytic (i.e. polymorphonuclear MDSC; PMN-MDSC) subsets that have immune suppressive functions on other immune cells to help cancers evade the immune response [48-50]. MDSCs were first found to have suppressive functions on $\mathrm{T}$ cells (CD8 ${ }^{+}$ $\mathrm{T}$ cells) to blunt the immune responses via induction of iNOS and ARG1 by production of reactive nitrogen species [48]. In early experiments both wild type and iNOS KO mice had increased numbers of $\mathrm{CD} 11 \mathrm{~b}^{+} \mathrm{Gr}-1^{+}$cells (now known as MDSCs) after treatment with granulocyte macrophage colony-stimulating factor (GM-CSF). However, immunosuppression as measured by inhibition of $\mathrm{T}$ cell proliferation by $\mathrm{CD} 11 \mathrm{~b}^{+} \mathrm{Gr}-1^{+}$cells was observed only in the iNOS expressing mice [51]. Interestingly, in NOS2 KO mice with implanted B16 melanomas, MDSCs are unable to suppress T cell activity [51]. Similarly, a PDE-5 inhibitor (sidenalfil) also inhibited decreased arginase and NOS2 expression as well as abrogated MDSC suppressive activity in B16 melanomas [52].

In melanoma, M-MDSC are elevated in the peripheral blood [49]. For example, in the B16 melanoma murine model, M-MDSCs produce $\mathrm{NO}$ and inhibit the proliferation of adoptively transferred $\mathrm{CD}^{+} \mathrm{T}$ cells and this inhibition of $\mathrm{T}$ cell proliferation was abrogated in the presence of an iNOS inhibitor (L-NMMA) [53]. Furthermore, NO produced by iNOS in the setting of low arginine (e.g. high Arginase expression) may produce reactive nitrogen species (e.g. peroxynitrite) and result in apoptosis of T cells [54]. Expression of the DC-HIL on M-MDSCs in the B16 model inhibits effector T cells by binding to syndecan-4 by a NO dependent mechanism [55]. Although, most models suggest that the monocytic population of MDSCs is important for melanoma there is at least one murine model driven by increased expression of the metabotropic glutamate receptor $1(\mathrm{Grm} 1)$ that suggests that iNOS expression in granulocytic MDSC and presumed production of NO is responsible for decreased $\mathrm{T}$ cell responses [56].

MDSCs inhibit T-cell function in melanoma both at the tumor itself and peripheral lymphoid organs [49]. In the RET (REearranged during Transfection) transgenic murine melanoma model, NOS2 expression was associated with increased MDSC recruitment by IL-12 producing $\gamma \delta \mathrm{T}$ cells and activation of T regulatory cells [57, 58]. VEGF secretion in the tumor microenvironment via iNOS dependent mechanisms also led to the recruitment of MDSC [59]. MDSC migration may also be inhibited by compounds such as OSU-53 (a thiazolidinedione) which reduces expression of iNOS within MDSCs derived from melanoma patients [60]. The calcium binding protein S100A9 also supported MDSC proliferation, recruitment to tumor and inhibited immune responses in cancer [61]. Tasquinimod abrogated S100A9 activity and inhibited MDSC suppression of T cells in a B16 melanoma model. Interestingly in this case, tasquinimod treatment increased M1 macrophage activity and iNOS expression [62]. Another recent mechanism of inhibition of MDSCs is that ibrutinib treatment in human MDSCs led to a reduction in NO production 
and inhibition of MDSC generation from normal peripheral mononuclear blood cells. Ibrutinib also resulted in decreased numbers of total MDSC in a murine B16 melanoma model [63]. Melanoma may also utilize MDSCs to evade the immune system in the context of chemotherapy administration. Interestingly, low dose chemotherapy such as cyclophosphamide increased NO production via increased numbers of MDSC [64]. Multiple mechanisms have been proposed across different cancer types, but the specific mechanisms of NO control of MDSC activity in melanoma are not entirely clear.

\section{NO modulates the production of cytokines and chemokines}

Cytokines and chemokines, through nitric oxide mediated mechanisms promote chemotaxis of immune-inhibitory cells, angiogenic processes, and alter cellular processes such as apoptosis. It has been demonstrated that increased NO concentration in the tumor microenvironment is associated with downregulation of the CXCL10 chemokine which serves to limit recruitment of immune cells such as plasmacytoid dendritic cells. CXCL10 had increased mRNA expression levels in melanoma samples obtained from patients without detectable iNOS expression [65]. CXCL10 is also responsible for the recruitment of CD8 ${ }^{+} \mathrm{T}$ cells, natural killer cells, monocytes and macrophages to the tumor microenvironment [66]. Clinically, it is not surprising that interferon-a (IFN-a) therapy upregulates CXCL10 in the serum of melanoma patients [67]. Furthermore, increased nNOS mRNA expression in 12 melanoma cell lines correlated with suppression of IFN-a activity as measured by downstream phosphorylation of STAT1 in T cells $\left(\mathrm{CD} 4^{+}\right.$and $\left.\mathrm{CD} 8^{+}\right)$and monocytes [68]. As expected, NONOate, a chemical that slowly releases NO and mimics NOS1 activity, induced a dose-dependent suppression of IFN-a p-STAT1 levels in T cells and monocytes that were cultured with the melanoma cell lines [68]. The suppression of IFN-a p-STAT1 activity by NO was reversed by specific NOS1 and NOS2 inhibitors in a dosedependent fashion [68]. Other cytokines such as IL-15 may actually slow melanoma tumor growth by increasing NO and IL-12 levels in macrophages contributing to apoptosis of individual melanoma cells [69]. Furthermore iNOS expressed in $\mathrm{CD}^{+} \mathrm{T}$ cells in the MT-RET1 melanoma model inhibits differentiation into $T_{\text {reg }}$ cells by limiting the activity of the cytokine TGF $\beta 1$ [70]. However, when B16 melanomas designed for C57Bl/6 mice were injected in Balb/c mice with mesenchymal cells treated with the inhibitory cytokines IFN- $\gamma$ and TNF-a, the melanomas are able to escape the immune system and cell death presumably by promoting iNOS expression in mesenchymal cells [71]. Decreased NO can therefore also be responsible for downregulation of cytokines. For example decreased NO concentration is associated with downregulation of angiogenic cytokines such as IL-8 in A375 and SB2 melanoma cell lines [65]. The angiogenic IL-8 cytokine has been shown to recruit suppressive MDSCs and have been reviewed elsewhere [72]. Other immune inhibitory cytokines such as IL-6 through NK/p38 MAPK pathway signaling, promoted AP-1 activity, and subsequently increased iNOS expression in B16 murine melanoma cells [73]. Therefore, the context in which NO is produced is important for modulating the levels of cytokines/ chemokines and for determining melanoma cell survival or death.

\section{There is evidence that nitric oxide both promotes and inhibits apoptosis}

Apoptosis of eukaryotic cells was initially thought to be mediated via two major pathways, the intrinsic/mitochondrial pathway and the extrinsic/death ligand pathway. However, in the 
final step of the cascade, the cell death is known to occur via a common pathway that includes activation of caspase 3. A third perforin or granzyme-dependent pathway utilized by cytotoxic $\mathrm{T}$ cells also leads to apoptotic cell death via caspase 3 activation [74]. NO plays a role in apoptosis of melanoma tumor cells and immune cells. Lymphocytes, in general, undergo apoptosis by nitration of key tyrosine residues inhibiting phosphorylation events [75]. In hypoxic murine melanoma models, IFN- $\gamma$ activated macrophages synthesized NO in a HIF-1 (hypoxia inducible factor 1) and iNOS dependent fashion to promote apoptosis of melanoma cells [76]. Early reviews discussed the general roles of NO in apoptosis including up-regulation of the tumor suppressor protein $\mathrm{p} 53$, activation of caspases, and downregulation of BCL2. [77]. Similar processes are felt to be in play in melanoma models. Human A375-S2 melanoma cells treated with evodiamine (inducer of iNOS), increased NO production, phosphorylated $\mathrm{p} 53$ and promoted apoptosis likely via a $\mathrm{p} 38$ and $\mathrm{NF} \mathrm{KB}$ dependent mechanism [78]. The addition of a NOS inhibitor (L-NAME) reduced the numbers of cells in the subG1 and G2/M cell cycle phases and reduced the ability of p53 to promote apoptosis [78]. The oncogenic protein MED-27 possibly abrogates apoptosis through increasing iNOS expression [79]. Inhibition of NO led to cell apoptosis in patient derived melanoma cell lines. When these cells were treated with a NO inhibitor (aminoguanidine), the mitochondrial membrane potential was altered to favor apoptosis, expression of caspases (1,3, and 6) increased, and BCL-2 expression levels decreased [80]. Interestingly, iNOS inhibition did not induce apoptosis in normal melanocytes as they did in melanoma cells derived from patients [80]. NO can also inhibit apoptosis by various pathways such as S-nitrosylation of activated caspases, kinases which are involved in activation of p53, possibly preventing assembly of the apoptosome [81]. Other NOS isoforms such as the nNOS isoform may also be responsible for melanoma cells escaping apoptosis. When nNOS expression was specifically reduced in melanoma cells, JunD, MMP-1, APE/Ref-1, and Bcl-2 expression increased leading to melanoma cell death presumably via apoptotic pathways [82]. Interestingly, different types of melanoma may have increased resistance to apoptosis as a direct function of NO activity. For example, amelanotic melanoma grown in hamster models demonstrated increased $\mathrm{NO}$ content and were more resistant to apoptosis compared to their melanocytic counterparts [83].

Additionally, mesenchymal stem cells lacking p53 (that are exposed to B16-F0 melanoma cells) in mice leads to upregulation of iNOS, increased immunosuppression, and in general increased tumor growth of melanoma cells [84].

Multiple natural products have been demonstrated to either promote or inhibit apoptosis in melanoma models. For example, capsaicin and resveretrol induced nNOS and iNOS production in A375 human melanoma cells and induced apoptosis via a cytochrome c dependent pathway [85]. In this case, the mechanism of apoptosis was facilitated via the extrinsic pathway including the death receptors DR4 and Fas (CD95) [85]. a-tocopheryl succinate, a derivative of vitamin $\mathrm{E}$, also led to increase NO production and apoptosis in B16-F1 murine melanoma [86]. Physalin A induces apoptosis in A375-S2 melanoma cells via the common pathway of apoptosis (caspase 3) via iNOS dependent pathways. Interestingly, induction of autophagy suppressed NO production in melanoma cells and inhibited those cells from undergoing apoptosis [87]. Rice bran polysaccharides mediate apoptosis of B16 melanoma cell lines in a dose dependent fashion by stimulating the 
production of NO likely in macrophages [88]. Similarly, B16-F1 melanoma cells in the pulmonary vasculature resulted in an increase in eNOS from pulmonary endothelial cells. NO concentration subsequently increased and resulted in apoptosis in melanoma cells [89]. In liver tissue, NO production in the sinusoids (endothelial cells and hepatocytes) is the source of NO for apoptosis of melanoma metastases [90]. Naturally occurring polyphenols (ceramide) decrease iNOS production by B16-F10 cells but increase eNOS production by the vascular endothelium. Subsequently there is increased NO and ceramide resulting in apoptosis of these cells. Interestingly, an extremely low or high concentration of NO decreases CCL2 expression, whereas intermediate levels of NO may increase BCL2 expression to inhibit apoptosis [91]. A naturally causing napthoquinone, 2-methoxy-6acetyl-7-methyljuglone (MAM) induces apoptosis by activation of the JNK pathway with subsequent inhibition of INOS expression and caspase dependent apoptosis [92]. Contrary to the effects of the natural product capsaicin, the natural product curcumin inhibited iNOS production of NO and resulted in apoptosis of melanoma cells [93]. Resveratrol abrogated the nitric oxide dependent apurinic/apyrimidinic endonuclease-1/redox factor-1 pathway that serves to promote expression of pro-growth genes such as Bcl-2 and MMP-1 [94].

Therefore, natural products have demonstrated to us that the relative concentrations of NO and the context in which it functions determines whether melanoma cells will undergo apoptosis.

Chemotherapy and targeted anti-cancer agents have also helped to elucidate the role of NO in apoptotic processes. In A375 melanoma cells, NO depletion followed by cisplatin treatment led to increased p53 and p21 levels with subsequent apoptosis via a cGMP independent process [95]. When iNOS is inhibited by L-NIL in A375 human melanoma cells lines, the cells become sensitive to VP-16 chemotherapy and undergo apoptosis as demonstrated by increased caspase 3 activation [96]. Similarly, when cisplatin is given to A375 cells after L-NIL administration BCL2 is downregulated and apoptosis is increased (TUNEL assay) [97]. Intercalating agents derived from anthracyclines such as WP-760, demonstrated inhibition of iNOS and likely activated the intrinsic mitochondrial apoptotic pathway [98]. Immune cells with increased NO levels may behave differently in the setting of chemotherapy. Dendritic cells (DCs) treated with a nitric oxide donor ex vivo and adoptively transferred into the B16-F1 model demonstrated resistance to apoptosis in the setting of cisplatin chemotherapy administration and administration of these cells resulted in slower tumor growth. The NO in the adoptively transferred DCs protected these cells from apoptosis by inhibiting the formation of the pro-apoptotic sphingolipid ceramid [99]. Targeted therapies such as vemurafenib (BRAF inhibitor) inhibited the growth of melanoma cells in part by inhibiting iNOS-dependent mTOR pathway activation [100]. $\beta$-blockers such as propranolol may decrease stress related increases in eNOS expression and subsequent B16 murine melanoma tumor growth [101]. Specific blockade of $\beta 3$-adrenergic receptors increased apoptosis in the setting of decreased iNOS activity [102]. In this section it was demonstrated that NO can both inhibit and activate apoptosis dependent on a multitude of factors via its three isoforms, eNOS, iNOS, and nNOS. 


\section{In some studies, the authors do not delineate apoptotic mechanisms of cell death or tumor growth but outline a clear association of NO with melanoma cell death}

For example, B16-F10 melanoma cells undergo lysis in the presence of macrophages via a TLR7/8 and NO dependent process [103]. Increased NO concentrations in hepatic sinusoidal endothelium led to increased levels of $\gamma$-glutamyl-cysteinyl-glycine (GSH) and subsequently increased TNF-a mediated cell death of B16-F10 melanoma cells [104]. The activity of cytotoxic T lymphocytes was also enhanced via NO by inhibiting the HIF1a pathway and subsequently decreasing inhibitory PD-L1 expression on B16-OVA murine melanoma cells [105]. Natural substances such as oligoesculin increased NO production in macrophages and promoted lysosomal activity with a subsequent reduction in tumor growth in B16-F10 melanoma models [106]. In contrast to the role that NO plays in promoting cytotoxicity, NO generated from MDSCs decreased the activity of cytotoxic T cells on melanoma cells. Addition of a NO scavenger (cPTIO) in this case led to a decrease in tumor growth [107]. Chemical compounds such as indole derivatives or methanol extracts of Solanum muricatum also inhibit NO production and human melanoma cell line growth [108, 109].

\section{Environmental factors in the vicinity of melanoma cells can either inhibit or promote metastasis via alteration of NO metabolism}

For example, hypoxic B16-F10 melanoma cells demonstrate increased number of lung metastases in murine models via suppression of the cGMP-dependent NO signaling pathway [110]. Some metastatic melanoma cell lines (e.g. K-1735) have increased iNOS mRNA expression compared to those that tend to metastasize to the lung [111, 112]. Interestingly, IFN- $\gamma$ and LPS resulted in increased iNOS expression only in non-metastatic melanoma cell lines and transfection of iNOS into the metastatic cell lines resulted in fewer lung metastases $[112,113]$. Inhibition of eNOS restored cell adhesion between melanoma cells and VCAM-1 allowing the melanoma cells to survive and after UVB radiation exposure [114]. Analogous to the murine experiments, human melanocytes stimulated with tumor necrosis factor- $\alpha$, interferon- $\gamma$, or lipopolysaccharide increased iNOS expression but induction appears to be reduced in melanoma cell lines such as SK-Mel-19 or O-Mel-2 [115]. Contrary to the mouse cell lines, human melanoma cells lines express iNOS at relatively low levels [115]. Just as we have seen with other processes, NO may also promote changes in the microenvironment to support tumor growth. Metastatic melanoma murine cell lines such as B16-BL6 have increased iNOS expression and numbers of metastases as compared to its B16 parent cell line by inhibiting lymphocyte mediated tumor immunity [116]. Melanocytes decrease adhesion to extracellular matrix elements such as fibronectin in the presence of nitric oxide in a concentration dependent manner [117]. Furthermore, when normal melanocytes are immortalized using traditional transfection techniques with HPV16 viral genes E6 and E7, these cells also detach from the extracellular matrix in the presence of NO likely via a cGMP dependent process [118]. Increased levels of NO under inflammatory conditions also increased levels of matrix metalloproteinase I via MAPK-dependent pathways in C32TG and Mewo melanoma cell lines to alter the extracellular matrix thereby promoting melanoma metastases [119]. Interestingly, the expression of leptin (normally found in states of obesity) in the melanoma microenvironment may increase NO concentration and endothelial progenitor cell proliferation leading to increased angiogenesis and melanoma tumor growth [120]. 


\section{Angiogenetic processes may be promoted or inhibited by NO}

There is evidence that NO can increase angiogenesis and thus promote tumor progression. Most of this evidence is derived from the association between NO and VEGF expression. For example a photoactive inhibitor of NOS (NS1) decreased VEGF production in A375 melanoma and resulted in G2/M cell cycle arrest. In a complementary ex vivo model of angiogenesis, tube formation of HUVEC cells (sign of angiogenesis) was decreased in the setting of the NS1 compound [121]. Furthermore, it was shown in 50 choroidal melanoma samples from humans that there was an association between increased protein levels of iNOS, HIF-1a, COX-2, and VEGF [35]. Using iNOS knock-out murine models, decreased iNOS expression inhibited the growth and metastases of B16 melanoma cells likely via a decrease of VEGF expression in the tumors and reduction in the tumor vasculature at the tumor invasive margin $[122,123]$. VEGF inhibitors such as axatinib decreased both tumor growth and iNOS expression in B16-F1 murine melanoma models [124]. Naturally occurring isothiocyanates may be utilized to inhibit $\mathrm{NO}$ and $\mathrm{TNFa}$ production and inhibit tumor specific angiogenesis [125]. An interesting side note is that (+) catechin also inhibits angiogenesis by decreasing production of VEGF and inhibiting NO production in LPStreated macrophages to potentially limit apoptotic processes [126]. In the A375 BRAF mutated human melanoma cell lines, VEGF directly increased iNOS protein levels and cell growth without affecting the protein levels of the nNOS and eNOS isoforms [127]. The eNOS and nNOS isoforms may have different effects on angiogenesis. Angiogenesis is promoted through adrenomedullin mediated eNOS signaling in melanoma [128]. In other studies it was suggested that B16-F10 melanoma cells utilize eNOS upregulation to promote VEGF mediated lymphangiogenesis [129]. On the other hand, inhibition of eNOS within the endothelial cells via a NOTCH dependent pathway may be the culprit for dysfunctional vascular formation and growth within tumors [130].

\section{iNOS expression and increased NO production correlates with a poor prognosis in melanoma}

As early as 2000, it was demonstrated that increased iNOS and nitrotyrosine levels were associated with poor survival in metastatic melanoma [131]. Immunohistochemistry staining of iNOS expression in tumors from 132 stage III melanoma patients demonstrated a strong association between iNOS expression and shortened survival time [132]. Similar studies performed by the Grimm laboratory demonstrated that iNOS expression was associated with a poor survival outcome [133]. Interestingly, subsets of melanoma that have increased proliferation rates such as BRAF mutated melanoma have also illustrated increased iNOS expression [134]. In patients with melanoma metastases to regional lymph nodes (stage III); there were decreased metastases to lung, liver and brain within three years in cases where the melanoma cells had decreased iNOS expression [135]. In another clinical trial of melanoma patients undergoing therapy with ipilimumab, increased NO production by MDSCs was associated with a worse outcome [136]. NOS1 expression in melanoma metastases was inversely correlated with therapeutic outcome to adoptive $\mathrm{T}$ cell therapy. However, in these patients, NOS2 and NOS3 expression in the melanoma tumors did not correlate with therapeutic outcome [68]. Although one study did not assess for overall survival, another study suggested that levels of nitric oxide increased in the peripheral blood of melanoma patients undergoing interferon- $a$ therapy [137]. Whereas iNOS expression 
levels were associated with overall survival level in melanoma, the same is not true for single nucleotide polymorphisms (SNPs). When single nucleotide polymorphisms (SNPs) were examined, no SNPs of the iNOS gene were associated with development of cutaneous melanoma whereas SNPs of the nNOS gene were associated with a risk of having moles and sunburns [138]. Interestingly, the use of iNOS as a biomarker may not be limited to cutaneous melanoma as iNOS may also be prognostic in uveal melanoma [139]. There is currently a phase Ib/II trial undergoing using omaveloxolone (NRF2 activator) to test the hypothesis that decreased reactive nitrogen species production will result in improved survival in patients with metastatic melanoma who are resistant to anti-PD-1 antibody therapy () [140].

\section{Melanogenesis and tumor formation is controlled by NO metabolism}

The pigment melanin has carcinogenic effects in addition to its well-known protective effects [141, 142]. Peroxynitrite, formed from superoxide and NO intermediates after UV exposure, transfers energy to melanin via chemiexcitation and induces cyclobutane pyrimidine dimers in DNA via radiationless energy transfer [141]. When B16-F10 cells were treated with a NO scavenger [MHY966] and subsequently implanted into mice, the tumors were smaller and contained decreased melanin content [143]. Premalignant melanocytes may be transformed into melanoma cells by anchorage blockade and promoting a state of eNOS uncoupling where eNOS preferentially produces high levels of superoxide to promote malignant transformation of a normal melanocyte cell line [144, 145]. This study reveals that it is not only the expression level of the NOS isoforms that is important but it is equally important to determine the nature of the free radical products that are generated. Other pathways may be involved in subsets of melanoma. For example in the BRAF mutated A375 murine models increased NO production increased expression microsomal prostaglandin E2 PGE2 synthase-1 and resulted in increased tumor growth [146]. It is important to remember that UVA mobilizes NO from skin stores to the systemic circulation where it lowers blood pressure [147]. Therefore, when formulating potential therapeutic interventions to limit tumor formation we must weigh the harmful effects of UV radiation versus potential benefits.

\section{Conclusion}

Although NO is primarily understood to be a gaseous signaling molecule, the evidence illustrates that $\mathrm{NO}$ has a multifaceted role in the development of melanoma. NO mediates effects through the melanoma cell itself, immune cell subsets (e.g. MDSC, DC, cytotoxic T cells, tumor associated macrophages), and the tumor microenvironment (e.g. vasculature, lymphatics). A dichotomy in this paper has been established in that NO can have both tumor promoting and inhibitory effects. Many of these effects are both concentration and context dependent. Further investigation to elucidate these individual pathways of NO modulation of melanoma progression can lead to possible new therapeutic strategies for melanoma.

\section{Acknowledgements}

J. Markowitz receives support from the Donald A Adam Comprehensive Melanoma Research Center at Moffitt Cancer Center and is also an Assistant Professor in the USF Morsani College of Medicine Department of Oncologic 
Sciences. The research was supported in part by the National Cancer Institute, part of the National Institutes of Health, under grant number P50 CA168536, Moffitt Skin Cancer SPORE. This work has been supported in part by the H. Lee Moffitt Cancer Center \& Research Institute; an NCI designated Comprehensive Cancer Center (P30CA076292).

\section{Abbreviations}

AMG

APE/Ref-1

ARG1

BCL2

BRAF

cGMP

cNOS

COX-2

c-PITO

CTL

CXCL10

DAF-FM

DC-HIL

DR4

eNOS

GM-CSF

HIF-1

IFN-a

IFN- $\gamma$

iNOS

JAK/STAT

JunD

L-NAME
Aminoguanidine

Apurinic/apyrimidinic endonuclease-1/redox factor -1

Arginine 1

B-cell lymphoma 2 gene

B- Rapidly Accelerated Fibrosarcoma

Cyclic guanosine monophosphate

constitutional nitric oxide synthase

cyclooxygenase-2

2-4-carboxyphenyl-4,4,5,5-tetramethylimidazoline-1-oxyl-3-oxide

cytotoxic T lymphocytes

chemokine (C-X-C motif) ligand 10

4-Amino-5-methylamino-2' ${ }^{\prime} 7^{\prime}$-difluorofluorescein

(Diaminofluorescein)

dendritic cell-associated, heparan sulfate proteoglycans-dependent integrin ligand

antigen $\mathrm{D}$ related 4

endothelial NOS

Granulocyte macrophage colony stimulating factor

hypoxia inducible factor-1

Interferon-alpha

Interferon-gamma

inducible NOS

Janus kinase/Signal Transducer and Activator of Transcription proteins

JunD is the transcription fractor protein product of the JUND gene

L-NG-Nitroarginine methyl ester 


\begin{tabular}{|c|c|}
\hline L-NIL & L-N6-(1-Iminoethyl)lysine \\
\hline L-NMMA & NG-monomethyl L-arginine \\
\hline LPS & Lipopolysaccharide \\
\hline MAPK & Mitogen-activated protein kinases \\
\hline MDSC & Myeloid derived stem cells \\
\hline MHY966 & 2-bromo-4-(5-chloro-benzol[d]thiazol-2-yl \\
\hline MMP-1 & Metalloproteinase-1 \\
\hline NAPDH & Nicotinamide adenine dinucleotide phosphate ( Reduced) \\
\hline nNOS & neuronal NOS \\
\hline NO & Nitric oxide \\
\hline NONOate & diethylaminedinitric oxide \\
\hline NOS & Nitric oxide synthase \\
\hline NOS1 & neuronal NOS \\
\hline NOS2 & inducible NOS \\
\hline NOS3 & endothelial NOS \\
\hline ONOO & Peroxynitrite \\
\hline PAPA NO & $\begin{array}{l}\text { (Z)-1- [N-(3-ammonio-propyl)-N-(n-propyl)amino]diazen-1-ium- } \\
\text { 1,2diolate }\end{array}$ \\
\hline PDE-5 & phosphodiesterase type 5 \\
\hline PD-L1 & Programmed cell death ligand 1 \\
\hline pO2 & Partial pressure of oxygen \\
\hline pSTAT1 & $\begin{array}{l}\text { phosphorylated Signal transducer and activator of transcription } 1 \\
\text { (STAT1) }\end{array}$ \\
\hline RET & rearranged during transfection gene \\
\hline ROS & reactive oxygen species \\
\hline SNAP & s-nitroso-n-acetyl-dl-penicilamine \\
\hline SNP & Single nucleotide polymorphisms \\
\hline TAM & tumor associated macrophage \\
\hline TGF $\beta 1$ & Transforming growth factor beta 1 \\
\hline VCAM-1 & Vascular cellular adhesion molecule- 1 \\
\hline
\end{tabular}


VEGF Vascular endothelial growth factor

\section{References}

[1]. Stuehr DJ, Enzymes of the L-arginine to nitric oxide pathway, The Journal of nutrition, 134 (2004) 2748S-2751S; discussion 2765S-2767S. [PubMed: 15465779]

[2]. Bogdan C, Nitric oxide synthase in innate and adaptive immunity: an update, Trends Immunol, 36 (2015) 161-178. [PubMed: 25687683]

[3]. Nathan C, Nitric oxide as a secretory product of mammalian cells, FASEB J, 6 (1992) 3051-3064. [PubMed: 1381691]

[4]. Bruch-Gerharz D, Ruzicka T, Kolb-Bachofen V, Nitric oxide and its implications in skin homeostasis and disease - a review, Arch Dermatol Res, 290 (1998) 643-651. [PubMed: 9879832]

[5]. Lundberg JO, Govoni M, Inorganic nitrate is a possible source for systemic generation of nitric oxide, Free Radic Biol Med, 37 (2004) 395-400. [PubMed: 15223073]

[6]. Lundberg JO, Weitzberg E, Gladwin MT, The nitrate-nitrite-nitric oxide pathway in physiology and therapeutics, Nat Rev Drug Discov, 7 (2008) 156-167. [PubMed: 18167491]

[7]. Tiso M, Schechter AN, Nitrate reduction to nitrite, nitric oxide and ammonia by gut bacteria under physiological conditions, PLoS One, 10 (2015) e0119712. [PubMed: 25803049]

[8]. Weitzberg E, Lundberg JO, Nonenzymatic nitric oxide production in humans, Nitric Oxide, 2 (1998) 1-7. [PubMed: 9706737]

[9]. Li H, Cui H, Kundu TK, Alzawahra W, Zweier JL, Nitric oxide production from nitrite occurs primarily in tissues not in the blood: critical role of xanthine oxidase and aldehyde oxidase, $\mathrm{J}$ Biol Chem, 283 (2008) 17855-17863. [PubMed: 18424432]

[10]. Opländer C, Suschek CV, The role of photolabile dermal nitric oxide derivates in ultraviolet radiation (UVR)-induced cell death, Int J Mol Sci, 14 (2012) 191-204. [PubMed: 23344028]

[11]. Opländer C, Deck A, Volkmar CM, Kirsch M, Liebmann J, Born M, van Abeelen F, van Faassen EE, Kröncke KD, Windolf J, Suschek CV, Mechanism and biological relevance of blue-light (420-453 nm)-induced nonenzymatic nitric oxide generation from photolabile nitric oxide derivates in human skin in vitro and in vivo, Free Radic Biol Med, 65 (2013) 1363-1377. [PubMed: 24121056]

[12]. Cortese-Krott MM, Fernandez BO, Kelm M, Butler AR, Feelisch M, On the chemical biology of the nitrite/sulfide interaction, Nitric Oxide, 46 (2015) 14-24. [PubMed: 25541073]

[13]. Pustelny K, Bielanska J, Plonka PM, Rosen GM, Elas M, In vivo spin trapping of nitric oxide from animal tumors, Nitric Oxide, 16 (2007) 202-208. [PubMed: 17113795]

[14]. Bryan NS, Grisham MB, Methods to detect nitric oxide and its metabolites in biological samples, Free Radic Biol Med, 43 (2007) 645-657. [PubMed: 17664129]

[15]. Planchet E, Kaiser WM, Nitric oxide (NO) detection by DAF fluorescence and chemiluminescence: a comparison using abiotic and biotic NO sources, J Exp Bot, 57 (2006) 3043-3055. [PubMed: 16893978]

[16]. Vannini F, Kashfi K, Nath N, The dual role of iNOS in cancer, Redox biology, 6 (2015) 334-343. [PubMed: 26335399]

[17]. Squadrito GL, Pryor WA, Oxidative chemistry of nitric oxide: the roles of superoxide, peroxynitrite, and carbon dioxide, Free Radic Biol Med, 25 (1998) 392-403. [PubMed: 9741578]

[18]. Stamler JS, Toone EJ, Lipton SA, Sucher NJ, (S)NO signals: translocation, regulation, and a consensus motif, Neuron, 18 (1997) 691-696. [PubMed: 9182795]

[19]. Hess DT, Matsumoto A, Kim SO, Marshall HE, Stamler JS, Protein S-nitrosylation: purview and parameters, Nat Rev Mol Cell Biol, 6 (2005) 150-166. [PubMed: 15688001]

[20]. Grimm EA, Sikora AG, Ekmekcioglu S, Molecular pathways: inflammation-associated nitricoxide production as a cancer-supporting redox mechanism and a potential therapeutic target, Clinical cancer research : an official journal of the American Association for Cancer Research, 19 (2013) 5557-5563. [PubMed: 23868870] 
[21]. Gould N, Doulias PT, Tenopoulou M, Raju K, Ischiropoulos H, Regulation of protein function and signaling by reversible cysteine S-nitrosylation, J Biol Chem, 288 (2013) 26473-26479. [PubMed: 23861393]

[22]. Chang CF, Diers AR, Hogg N, Cancer cell metabolism and the modulating effects of nitric oxide, Free Radic Biol Med, 79 (2015) 324-336. [PubMed: 25464273]

[23]. Marshall HE, Gow A, Regulation of cellular processes by S-nitrosylation. Preface, Biochim Biophys Acta, 1820 (2012) 673-674. [PubMed: 22554496]

[24]. Ekmekcioglu S, Tang CH, Grimm EA, NO news is not necessarily good news in cancer, Current cancer drug targets, 5 (2005) 103-115. [PubMed: 15810875]

[25]. Liu Z, Cao J, Ma Q, Gao X, Ren J, Xue Y, GPS-YNO2: computational prediction of tyrosine nitration sites in proteins, Mol Biosyst, 7 (2011) 1197-1204. [PubMed: 21258675]

[26]. van der Vliet A, O’Neill CA, Halliwell B, Cross CE, Kaur H, Aromatic hydroxylation and nitration of phenylalanine and tyrosine by peroxynitrite. Evidence for hydroxyl radical production from peroxynitrite, FEBS Lett, 339 (1994) 89-92. [PubMed: 8313984]

[27]. Radi R, Protein tyrosine nitration: biochemical mechanisms and structural basis of functional effects, Acc Chem Res, 46 (2013) 550-559. [PubMed: 23157446]

[28]. Larsen FJ, Schiffer TA, Weitzberg E, Lundberg JO, Regulation of mitochondrial function and energetics by reactive nitrogen oxides, Free Radic Biol Med, 53 (2012) 1919-1928. [PubMed: 22989554]

[29]. Godoy LC, Munoz-Pinedo C, Castro L, Cardaci S, Schonhoff CM, King M, Tortora V, Marin M, Miao Q, Jiang JF, Kapralov A, Jemmerson R, Silkstone GG, Patel JN, Evans JE, Wilson MT, Green DR, Kagan VE, Radi R, Mannick JB, Disruption of the M80-Fe ligation stimulates the translocation of cytochrome $\mathrm{c}$ to the cytoplasm and nucleus in nonapoptotic cells, Proc Natl Acad Sci U S A, 106 (2009) 2653-2658. [PubMed: 19196960]

[30]. Grimm EA, Ellerhorst J, Tang CH, Ekmekcioglu S, Constitutive intracellular production of iNOS and NO in human melanoma: possible role in regulation of growth and resistance to apoptosis, Nitric Oxide, 19 (2008) 133-137. [PubMed: 18472017]

[31]. Joshi M, Strandhoy J, White WL, Nitric oxide synthase activity is up-regulated in melanoma cell lines: a potential mechanism for metastases formation, Melanoma research, 6 (1996) 121-126. [PubMed: 8791269]

[32]. Ahmed B, Van Den Oord JJ, Expression of the inducible isoform of nitric oxide synthase in pigment cell lesions of the skin, The British journal of dermatology, 142 (2000) 432-440. [PubMed: 10735946]

[33]. Massi D, De Nisi MC, Franchi A, Mourmouras V, Baroni G, Panelos J, Santucci M, Miracco C, Inducible nitric oxide synthase expression in melanoma: implications in lymphangiogenesis, Modern pathology : an official journal of the United States and Canadian Academy of Pathology, Inc, 22 (2009) 21-30.

[34]. Coit DG, Thompson JA, Algazi A, Andtbacka R, Bichakjian CK, Carson WE 3rd, Daniels GA, DiMaio D, Ernstoff M, Fields RC, Fleming MD, Gonzalez R, Guild V, Halpern AC, Hodi FS Jr., Joseph RW, Lange JR, Martini MC, Materin MA, Olszanski AJ, Ross MI, Salama AK, Skitzki J, Sosman J, Swetter SM, Tanabe KK, Torres-Roca JF, Trisal V, Urist MM, McMillian N, Engh A, Melanoma, Version 2.2016, NCCN Clinical Practice Guidelines in Oncology, J Natl Compr Canc Netw, 14 (2016) 450-473. [PubMed: 27059193]

[35]. Xu Q, Zhao GQ, Zhao J, Lin H, Mou YY, Wang Q, Sun WR, Expression and significance of factors related to angiogenesis in choroidal melanoma, International journal of ophthalmology, 4 (2011) 49-54. [PubMed: 22553608]

[36]. Ahmed B, Van Den Oord JJ, Expression of the neuronal isoform of nitric oxide synthase (nNOS) and its inhibitor, protein inhibitor of nNOS, in pigment cell lesions of the skin, The British journal of dermatology, 141 (1999) 12-19. [PubMed: 10417510]

[37]. Huang SH, Hsu MH, Hsu SC, Yang JS, Huang WW, Huang AC, Hsiao YP, Yu CC, Chung JG, Phenethyl isothiocyanate triggers apoptosis in human malignant melanoma A375.S2 cells through reactive oxygen species and the mitochondria-dependent pathways, Human \& experimental toxicology, 33 (2014) 270-283. [PubMed: 23760257] 
[38]. Chin MP, Deen WM, Prediction of nitric oxide concentrations in melanomas, Nitric Oxide, 23 (2010) 319-326. [PubMed: 20854923]

[39]. Thomas DD, Wink DA, NOS2 as an Emergent Player in Progression of Cancer, Antioxidants \& redox signaling, 26 (2017) 963-965. [PubMed: 28506076]

[40]. Massi D, Marconi C, Franchi A, Bianchini F, Paglierani M, Ketabchi S, Miracco C, Santucci M, Calorini L, Arginine metabolism in tumor-associated macrophages in cutaneous malignant melanoma: evidence from human and experimental tumors, Human pathology, 38 (2007) 15161525. [PubMed: 17640716]

[41]. Calorini L, Bianchini F, Mannini A, Mugnai G, Ruggieri S, Enhancement of nitric oxide release in mouse inflammatory macrophages co-cultivated with tumor cells of a different origin, Clinical \& experimental metastasis, 22 (2005) 413-419. [PubMed: 16283484]

[42]. Egilmez NK, Harden JL, Virtuoso LP, Schwendener RA, Kilinc MO, Nitric oxide short-circuits interleukin-12-mediated tumor regression, Cancer Immunol Immunother, 60 (2011) 839-845. [PubMed: 21387108]

[43]. Rothe H, Hartmann B, Geerlings P, Kolb H, Interleukin-12 gene-expression of macrophages is regulated by nitric oxide, Biochem Biophys Res Commun, 224 (1996) 159-163. [PubMed: 8694804]

[44]. Diao J, Mikhailova A, Tang M, Gu H, Zhao J, Cattral MS, Immunostimulatory conventional dendritic cells evolve into regulatory macrophage-like cells, Blood, 119 (2012) 4919-4927. [PubMed: 22490680]

[45]. Place AE, Suh N, Williams CR, Risingsong R, Honda T, Honda Y, Gribble GW, Leesnitzer LM, Stimmel JB, Willson TM, Rosen E, Sporn MB, The novel synthetic triterpenoid, CDDOimidazolide, inhibits inflammatory response and tumor growth in vivo, Clinical cancer research : an official journal of the American Association for Cancer Research, 9 (2003) 2798-2806. [PubMed: 12855660]

[46]. Abe K, Harada M, Tamada K, Ito O, Li T, Nomoto K, Early-appearing tumor-infiltrating natural killer cells play an important role in the nitric oxide production of tumor-associated macrophages through their interferon production, Cancer Immunol Immunother, 45 (1998) 225-233. [PubMed: 9439645]

[47]. Klug F, Prakash H, Huber PE, Seibel T, Bender N, Halama N, Pfirschke C, Voss RH, Timke C, Umansky L, Klapproth K, Schakel K, Garbi N, Jager D, Weitz J, Schmitz-Winnenthal H, Hammerling GJ, Beckhove P, Low-dose irradiation programs macrophage differentiation to an iNOS(+)/M1 phenotype that orchestrates effective T cell immunotherapy, Cancer cell, 24 (2013) 589-602. [PubMed: 24209604]

[48]. Gabrilovich DI, Ostrand-Rosenberg S, Bronte V, Coordinated regulation of myeloid cells by tumours, Nat Rev Immunol, 12 (2012) 253-268. [PubMed: 22437938]

[49]. Kumar V, Patel S, Tcyganov E, Gabrilovich DI, The Nature of Myeloid-Derived Suppressor Cells in the Tumor Microenvironment, Trends Immunol, 37 (2016) 208-220. [PubMed: 26858199]

[50]. Wesolowski R, Markowitz J, Carson WE 3rd, Myeloid derived suppressor cells - a new therapeutic target in the treatment of cancer, J Immunother Cancer, 1 (2013) 10. [PubMed: 24829747]

[51]. Mazzoni A, Bronte V, Visintin A, Spitzer JH, Apolloni E, Serafini P, Zanovello P, Segal DM, Myeloid suppressor lines inhibit T cell responses by an NO-dependent mechanism, J Immunol, 168 (2002) 689-695. [PubMed: 11777962]

[52]. Serafini P, Meckel K, Kelso M, Noonan K, Califano J, Koch W, Dolcetti L, Bronte V, Borrello I, Phosphodiesterase-5 inhibition augments endogenous antitumor immunity by reducing myeloidderived suppressor cell function, J Exp Med, 203 (2006) 2691-2702. [PubMed: 17101732]

[53]. Hosoi A, Matsushita H, Shimizu K, Fujii S, Ueha S, Abe J, Kurachi M, Maekawa R, Matsushima $\mathrm{K}$, Kakimi K, Adoptive cytotoxic T lymphocyte therapy triggers a counter-regulatory immunosuppressive mechanism via recruitment of myeloid-derived suppressor cells, International journal of cancer. Journal international du cancer, 134 (2014) 1810-1822. [PubMed: 24150772]

[54]. Bronte V, Serafini P, Mazzoni A, Segal DM, Zanovello P, L-arginine metabolism in myeloid cells controls T-lymphocyte functions, Trends Immunol, 24 (2003) 302-306. [PubMed: 12810105] 
[55]. Chung JS, Tamura K, Cruz PD Jr., Ariizumi K, DC-HIL-expressing myelomonocytic cells are critical promoters of melanoma growth, J Invest Dermatol, 134 (2014) 2784-2794. [PubMed: 24936834]

[56]. Mairhofer DG, Ortner D, Tripp CH, Schaffenrath S, Fleming V, Heger L, Komenda K, Reider D, Dudziak D, Chen S, Becker JC, Flacher V, Stoitzner P, Impaired gp100-Specific CD8 T-Cell Responses in the Presence of Myeloid-Derived Suppressor Cells in a Spontaneous Mouse Melanoma Model, J Invest Dermatol, (2015).

[57]. Douguet L, Bod L, Lengagne R, Labarthe L, Kato M, Avril MF, Prevost-Blondel A, Nitric oxide synthase 2 is involved in the pro-tumorigenic potential of gammadelta17 $\mathrm{T}$ cells in melanoma, Oncoimmunology, 5 (2016) e1208878. [PubMed: 27622078]

[58]. Dabbeche-Bouricha E, Araujo LM, Kato M, Prevost-Blondel A, Garchon HJ, Rapid dissemination of RET-transgene-driven melanoma in the presence of non-obese diabetic alleles: Critical roles of Dectin-1 and Nitric-oxide synthase type 2, Oncoimmunology, 5 (2016) e1100793. [PubMed: 27467912]

[59]. Jayaraman P, Parikh F, Lopez-Rivera E, Hailemichael Y, Clark A, Ma G, Cannan D, Ramacher M, Kato M, Overwijk WW, Chen SH, Umansky VY, Sikora AG, Tumor-expressed inducible nitric oxide synthase controls induction of functional myeloid-derived suppressor cells through modulation of vascular endothelial growth factor release, J Immunol, 188 (2012) 5365-5376. [PubMed: 22529296]

[60]. Trikha P, Plews RL, Stiff A, Gautam S, Hsu V, Abood D, Wesolowski R, Landi I, Mo X, Phay J, Chen CS, Byrd J, Caligiuri M, Tridandapani S, Carson W, Targeting myeloid-derived suppressor cells using a novel adenosine monophosphate-activated protein kinase (AMPK) activator, Oncoimmunology, 5 (2016) e1214787. [PubMed: 27757311]

[61]. Markowitz J, Carson WE 3rd, Review of S100A9 biology and its role in cancer, Biochim Biophys Acta, 1835 (2013) 100-109. [PubMed: 23123827]

[62]. Shen L, Sundstedt A, Ciesielski M, Miles KM, Celander M, Adelaiye R, Orillion A, Ciamporcero E, Ramakrishnan S, Ellis L, Fenstermaker R, Abrams SI, Eriksson H, Leanderson T, Olsson A, Pili R, Tasquinimod modulates suppressive myeloid cells and enhances cancer immunotherapies in murine models, Cancer immunology research, 3 (2015) 136-148. [PubMed: 25370534]

[63]. Stiff A, Trikha P, Wesolowski R, Kendra K, Hsu V, Uppati S, McMichael EL, Duggan M, Campbell A, Keller K, Landi I, Zhong Y, Dubovsky J, Howard JH, Yu L, Harrington B, Old M, Reiff S, Mace T, Tridandapani S, Muthusamy N, Caligiuri M, Byrd JC, Carson WE, Myeloidderived suppressor cells express Bruton's tyrosine kinase and can be depleted in tumor bearing hosts by ibrutinib treatment, Cancer Res, (2016).

[64]. Sevko A, Sade-Feldman M, Kanterman J, Michels T, Falk CS, Umansky L, Ramacher M, Kato M, Schadendorf D, Baniyash M, Umansky V, Cyclophosphamide promotes chronic inflammation-dependent immunosuppression and prevents antitumor response in melanoma, $\mathrm{J}$ Invest Dermatol, 133 (2013) 1610-1619. [PubMed: 23223128]

[65]. Tanese K, Grimm EA, Ekmekcioglu S, The role of melanoma tumor-derived nitric oxide in the tumor inflammatory microenvironment: its impact on the chemokine expression profile, including suppression of CXCL10, International journal of cancer. Journal international du cancer, 131 (2012) 891-901. [PubMed: 21953496]

[66]. Dufour JH, Dziejman M, Liu MT, Leung JH, Lane TE, Luster AD, IFN-gamma-inducible protein 10 (IP-10; CXCL10)-deficient mice reveal a role for IP-10 in effector T cell generation and trafficking, J Immunol, 168 (2002) 3195-3204. [PubMed: 11907072]

[67]. Dengel LT, Norrod AG, Gregory BL, Clancy-Thompson E, Burdick MD, Strieter RM, Slingluff CL, Mullins DW, Interferons induce CXCR3-cognate chemokine production by human metastatic melanoma, J Immunother, 33 (2010) 965-974. [PubMed: 20948440]

[68]. Liu Q, Tomei S, Ascierto ML, De Giorgi V, Bedognetti D, Dai C, Uccellini L, Spivey T, Pos Z, Thomas J, Reinboth J, Murtas D, Zhang Q, Chouchane L, Weiss GR, Slingluff CL Jr., Lee PP, Rosenberg SA, Alter H, Yao K, Wang E, Marincola FM, Melanoma NOS1 expression promotes dysfunctional IFN signaling, The Journal of clinical investigation, 124 (2014) 2147-2159. [PubMed: 24691438] 
[69]. Davies E, Reid S, Medina MF, Lichty B, Ashkar AA, IL-15 has innate anti-tumor activity independent of NK and CD8 T cells, Journal of leukocyte biology, 88 (2010) 529-536. [PubMed: 20538758]

[70]. Jayaraman P, Alfarano MG, Svider PF, Parikh F, Lu G, Kidwai S, Xiong H, Sikora AG, iNOS expression in CD4+ T cells limits Treg induction by repressing TGFbeta1: combined iNOS inhibition and Treg depletion unmask endogenous antitumor immunity, Clinical cancer research : an official journal of the American Association for Cancer Research, 20 (2014) 6439-6451. [PubMed: 25278453]

[71]. Han Z, Tian Z, Lv G, Zhang L, Jiang G, Sun K, Wang C, Bu X, Li R, Shi Y, Wu M, Wei L, Immunosuppressive effect of bone marrow-derived mesenchymal stem cells in inflammatory microenvironment favours the growth of B16 melanoma cells, Journal of cellular and molecular medicine, 15 (2011) 2343-2352. [PubMed: 21091630]

[72]. David JM, Dominguez C, Hamilton DH, Palena C, The IL-8/IL-8R Axis: A Double Agent in Tumor Immune Resistance, Vaccines (Basel), 4 (2016).

[73]. Kang KW, Wagley Y, Kim HW, Pokharel YR, Chung YY, Chang IY, Kim JJ, Moon JS, Kim YK, Nah SY, Kang HS, Oh JW, Novel role of IL-6/SIL-6R signaling in the expression of inducible nitric oxide synthase (iNOS) in murine B16, metastatic melanoma clone F10.9, cells, Free Radic Biol Med, 42 (2007) 215-227. [PubMed: 17189827]

[74]. Elmore S, Apoptosis: a review of programmed cell death, Toxicol Pathol, 35 (2007) 495-516. [PubMed: 17562483]

[75]. Brito C, Naviliat M, Tiscornia AC, Vuillier F, Gualco G, Dighiero G, Radi R, Cayota AM, Peroxynitrite inhibits $\mathrm{T}$ lymphocyte activation and proliferation by promoting impairment of tyrosine phosphorylation and peroxynitrite-driven apoptotic death, J Immunol, 162 (1999) 33563366. [PubMed: 10092790]

[76]. Tendler DS, Bao C, Wang T, Huang EL, Ratovitski EA, Pardoll DA, Lowenstein CJ, Intersection of interferon and hypoxia signal transduction pathways in nitric oxide-induced tumor apoptosis, Cancer Res, 61 (2001) 3682-3688. [PubMed: 11325839]

[77]. Brune B, von Knethen A, Sandau KB, Nitric oxide (NO): an effector of apoptosis, Cell death and differentiation, 6 (1999) 969-975. [PubMed: 10556974]

[78]. Yang J, Wu LJ, Tashiro S, Onodera S, Ikejima T, Nitric oxide activated by p38 and NF-kappaB facilitates apoptosis and cell cycle arrest under oxidative stress in evodiamine-treated human melanoma A375-S2 cells, Free Radic Res, 42 (2008) 1-11. [PubMed: 18324518]

[79]. Tang R, Xu X, Yang W, Yu W, Hou S, Xuan Y, Tang Z, Zhao S, Chen Y, Xiao X, Huang W, Guo W, Li M, Deng W, MED27 promotes melanoma growth by targeting AKT/MAPK and NFkappaB/iNOS signaling pathways, Cancer Lett, 373 (2016) 77-87. [PubMed: 26797421]

[80]. Salvucci O, Carsana M, Bersani I, Tragni G, Anichini A, Antiapoptotic role of endogenous nitric oxide in human melanoma cells, Cancer Res, 61 (2001) 318-326. [PubMed: 11196180]

[81]. Brune B, Nitric oxide: NO apoptosis or turning it ON?, Cell death and differentiation, 10 (2003) 864-869. [PubMed: 12867993]

[82]. Yang Z, Misner B, Ji H, Poulos TL, Silverman RB, Meyskens FL, Yang S, Targeting nitric oxide signaling with nNOS inhibitors as a novel strategy for the therapy and prevention of human melanoma, Antioxidants \& redox signaling, 19 (2013) 433-447. [PubMed: 23199242]

[83]. Kozlowska K, Cichorek M, Zarzeczna M, A study on nitric oxide secretion by transplantable melanoma cell lines with regard to their spontaneous apoptosis, Neoplasma, 48 (2001) 496-500. [PubMed: 11949844]

[84]. Huang Y, Yu P, Li W, Ren G, Roberts AI, Cao W, Zhang X, Su J, Chen X, Chen Q, Shou P, Xu C, Du L, Lin L, Xie N, Zhang L, Wang Y, Shi Y, p53 regulates mesenchymal stem cell-mediated tumor suppression in a tumor microenvironment through immune modulation, Oncogene, 33 (2014) 3830-3838. [PubMed: 23975435]

[85]. Kim MY, Nitric oxide triggers apoptosis in A375 human melanoma cells treated with capsaicin and resveratrol, Molecular medicine reports, 5 (2012) 585-591. [PubMed: 22143933]

[86]. Fukuzawa K, Kogure K, Morita M, Hama S, Manabe S, Tokumura A, Enhancement of nitric oxide and superoxide generations by alpha-tocopheryl succinate and its apoptotic and anticancer effects, Biochemistry. Biokhimiia, 69 (2004) 50-57. [PubMed: 14972018] 
[87]. He H, Feng YS, Zang LH, Liu WW, Ding LQ, Chen LX, Kang N, Hayashi T, Tashiro S, Onodera S, Qiu F, Ikejima T, Nitric oxide induces apoptosis and autophagy; autophagy down-regulates NO synthesis in physalin A-treated A375-S2 human melanoma cells, Food and chemical toxicology : an international journal published for the British Industrial Biological Research Association, 71 (2014) 128135.

[88]. Wang L, Li Y, Zhu L, Yin R, Wang R, Luo X, Li Y, Li Y, Chen Z, Antitumor activities and immunomodulatory of rice bran polysaccharides and its sulfates in vitro, Int J Biol Macromol, 88 (2016) 424-432. [PubMed: 27064087]

[89]. Qiu H, Orr FW, Jensen D, Wang HH, McIntosh AR, Hasinoff BB, Nance DM, Pylypas S, Qi K, Song C, Muschel RJ, Al-Mehdi AB, Arrest of B16 melanoma cells in the mouse pulmonary microcirculation induces endothelial nitric oxide synthase-dependent nitric oxide release that is cytotoxic to the tumor cells, Am J Pathol, 162 (2003) 403-412. [PubMed: 12547699]

[90]. Qi K, Qiu H, Rutherford J, Zhao Y, Nance DM, Orr FW, Direct visualization of nitric oxide release by liver cells after the arrest of metastatic tumor cells in the hepatic microvasculature, The Journal of surgical research, 119 (2004) 29-35. [PubMed: 15126078]

[91]. Ferrer P, Asensi M, Priego S, Benlloch M, Mena S, Ortega A, Obrador E, Esteve JM, Estrela JM, Nitric oxide mediates natural polyphenol-induced Bcl-2 down-regulation and activation of cell death in metastatic B16 melanoma, J Biol Chem, 282 (2007) 2880-2890. [PubMed: 17135264]

[92]. Sun W, Bao J, Lin W, Gao H, Zhao W, Zhang Q, Leung CH, Ma DL, Lu J, Chen X, 2Methoxy-6-acetyl-7-methyljuglone (MAM), a natural naphthoquinone, induces NO-dependent apoptosis and necroptosis by H2O2-dependent JNK activation in cancer cells, Free Radic Biol Med, 92 (2016) 61-77. [PubMed: 26802903]

[93]. Zheng M, Ekmekcioglu S, Walch ET, Tang CH, Grimm EA, Inhibition of nuclear factor-kappaB and nitric oxide by curcumin induces G2/M cell cycle arrest and apoptosis in human melanoma cells, Melanoma research, 14 (2004) 165-171. [PubMed: 15179184]

[94]. Yang Z, Yang S, Misner BJ, Chiu R, Liu F, Meyskens FL Jr., Nitric oxide initiates progression of human melanoma via a feedback loop mediated by apurinic/apyrimidinic endonuclease- $1 /$ redox factor-1, which is inhibited by resveratrol, Molecular cancer therapeutics, 7 (2008) 3751-3760. [PubMed: 19074850]

[95]. Tang CH, Grimm EA, Depletion of endogenous nitric oxide enhances cisplatin-induced apoptosis in a p53-dependent manner in melanoma cell lines, J Biol Chem, 279 (2004) 288-298. [PubMed: 14576150]

[96]. Sinha BK, Kumar A, Bhattacharjee S, Espey MG, Mason RP, Effect of nitric oxide on the anticancer activity of the topoisomerase-active drugs etoposide and adriamycin in human melanoma cells, The Journal of pharmacology and experimental therapeutics, 347 (2013) 607614. [PubMed: 24049059]

[97]. Sikora AG, Gelbard A, Davies MA, Sano D, Ekmekcioglu S, Kwon J, Hailemichael Y, Jayaraman P, Myers JN, Grimm EA, Overwijk WW, Targeted inhibition of inducible nitric oxide synthase inhibits growth of human melanoma in vivo and synergizes with chemotherapy, Clinical cancer research : an official journal of the American Association for Cancer Research, 16 (2010) 1834-1844. [PubMed: 20215556]

[98]. Zheng M, Priebe W, Walch ET, Roth KG, Han M, Tang CH, Lee S, Poindexter NJ, Fokt I, Grimm EA, WP760, a melanoma selective drug, Cancer Chemother Pharmacol, 60 (2007) 625-633. [PubMed: 17195067]

[99]. Perrotta C, Bizzozero L, Falcone S, Rovere-Querini P, Prinetti A, Schuchman EH, Sonnino S, Manfredi AA, Clementi E, Nitric oxide boosts chemoimmunotherapy via inhibition of acid sphingomyelinase in a mouse model of melanoma, Cancer Res, 67 (2007) 7559-7564. [PubMed: 17699758]

[100]. Lopez-Rivera E, Jayaraman P, Parikh F, Davies MA, Ekmekcioglu S, Izadmehr S, Milton DR, Chipuk JE, Grimm EA, Estrada Y, Aguirre-Ghiso J, Sikora AG, Inducible nitric oxide synthase drives mTOR pathway activation and proliferation of human melanoma by reversible nitrosylation of TSC2, Cancer Res, 74 (2014) 1067-1078. [PubMed: 24398473]

[101]. Barbieri A, Palma G, Rosati A, Giudice A, Falco A, Petrillo A, Petrillo M, Bimonte S, Di Benedetto M, Esposito G, Stiuso P, Abbruzzese A, Caraglia M, Arra C, Role of endothelial nitric 
oxide synthase (eNOS) in chronic stress-promoted tumour growth, Journal of cellular and molecular medicine, 16 (2012) 920-926. [PubMed: 21722303]

[102]. Dal Monte M, Fornaciari I, Nicchia GP, Svelto M, Casini G, Bagnoli P, beta3-adrenergic receptor activity modulates melanoma cell proliferation and survival through nitric oxide signaling, Naunyn Schmiedebergs Arch Pharmacol, 387 (2014) 533-543. [PubMed: 24599317]

[103]. Singh M, Khong H, Dai Z, Huang XF, Wargo JA, Cooper ZA, Vasilakos JP, Hwu P, Overwijk WW, Effective innate and adaptive antimelanoma immunity through localized TLR7/8 activation, J Immunol, 193 (2014) 4722-4731. [PubMed: 25252955]

[104]. Ortega AL, Carretero J, Obrador E, Gambini J, Asensi M, Rodilla V, Estrela JM, Tumor cytotoxicity by endothelial cells. Impairment of the mitochondrial system for glutathione uptake in mouse B16 melanoma cells that survive after in vitro interaction with the hepatic sinusoidal endothelium, J Biol Chem, 278 (2003) 13888-13897. [PubMed: 12578841]

[105]. Barsoum IB, Smallwood CA, Siemens DR, Graham CH, A mechanism of hypoxia-mediated escape from adaptive immunity in cancer cells, Cancer Res, 74 (2014) 665-674. [PubMed: 24336068]

[106]. Mokdad Bzeouich I, Mustapha N, Sassi A, Ghedira K, Ghoul M, Chebil L, Luis J, ChekirGhedira L, Oligoesculin fraction induces anti-tumor effects and promotes immune responses on B16-F10 mice melanoma, Tumour Biol, 37 (2016) 11349-11358. [PubMed: 26960691]

[107]. Hirano K, Hosoi A, Matsushita H, Iino T, Ueha S, Matsushima K, Seto Y, Kakimi K, The nitric oxide radical scavenger carboxy-PTIO reduces the immunosuppressive activity of myeloidderived suppressor cells and potentiates the antitumor activity of adoptive cytotoxic $\mathrm{T}$ lymphocyte immunotherapy, Oncoimmunology, 4 (2015) e1019195. [PubMed: 26405569]

[108]. Sinicropi MS, Caruso A, Conforti F, Marrelli M, El Kashef H, Lancelot JC, Rault S, Statti GA, Menichini F, Synthesis, inhibition of NO production and antiproliferative activities of some indole derivatives, J Enzyme Inhib Med Chem, 24 (2009) 1148-1153. [PubMed: 19555184]

[109]. Shathish K, Sakthivel KM, Guruvayoorappan C, Protective Effect of Solanum muricatum on Tumor Metastasis by Regulating Inflammatory Mediators and Nuclear Factor-Kappa B Subunits, J Environ Pathol Toxicol Oncol, 34 (2015) 249-262. [PubMed: 26349607]

[110]. Postovit LM, Adams MA, Lash GE, Heaton JP, Graham CH, Nitric oxide-mediated regulation of hypoxia-induced B16F10 melanoma metastasis, International journal of cancer. Journal international du cancer, 108 (2004) 47-53. [PubMed: 14618614]

[111]. Dong Z, Staroselsky AH, Qi X, Xie K, Fidler IJ, Inverse correlation between expression of inducible nitric oxide synthase activity and production of metastasis in K-1735 murine melanoma cells, Cancer Res, 54 (1994) 789-793. [PubMed: 7508336]

[112]. Gerecitano J, Perle MA, Vilcek J, Transcriptional basis for the differences in inducible nitric oxide synthase (iNOS) expression between nonmetastatic and metastatic murine melanoma cell lines, Journal of interferon \& cytokine research : the official journal of the International Society for Interferon and Cytokine Research, 19 (1999) 393-405.

[113]. Xie K, Huang S, Dong Z, Juang SH, Gutman M, Xie QW, Nathan C, Fidler IJ, Transfection with the inducible nitric oxide synthase gene suppresses tumorigenicity and abrogates metastasis by K-1735 murine melanoma cells, J Exp Med, 181 (1995) 1333-1343. [PubMed: 7535333]

[114]. Liu W, Wu S, The roles of Akt and NOSs in regulation of VLA-4-mediated melanoma cell adhesion to endothelial VCAM-1 after UVB-irradiation, Archives of biochemistry and biophysics, 508 (2011) 192-197. [PubMed: 21129359]

[115]. Fecker LF, Eberle J, Orfanos CE, Geilen CC, Inducible nitric oxide synthase is expressed in normal human melanocytes but not in melanoma cells in response to tumor necrosis factor-alpha, interferon-gamma, and lipopolysaccharide, J Invest Dermatol, 118 (2002) 1019-1025. [PubMed: 12060397]

[116]. Zhang XM, Xu Q, Metastatic melanoma cells escape from immunosurveillance through the novel mechanism of releasing nitric oxide to induce dysfunction of immunocytes, Melanoma research, 11 (2001) 559-567. [PubMed: 11725202]

[117]. Ivanova K, Le Poole IC, Gerzer R, Westerhof W, Das PK, Effect of nitric oxide on the adhesion of human melanocytes to extracellular matrix components, J Pathol, 183 (1997) 469-476. [PubMed: 9496265] 
[118]. Ivanova K, Lambers B, van den Wijngaard R, Le Poole IC, Grigorieva O, Gerzer R, Das PK, Immortalization of human melanocytes does not alter the de novo properties of nitric oxide to induce cell detachment from extracellular matrix components via cGMP, In vitro cellular \& developmental biology. Animal, 44 (2008) 385-395. [PubMed: 18594937]

[119]. Ishii Y, Ogura T, Tatemichi M, Fujisawa H, Otsuka F, Esumi H, Induction of matrix metalloproteinase gene transcription by nitric oxide and mechanisms of MMP-1 gene induction in human melanoma cell lines, International journal of cancer. Journal international du cancer, 103 (2003) 161-168. [PubMed: 12455029]

[120]. Amjadi F, Javanmard SH, Zarkesh-Esfahani H, Khazaei M, Narimani M, Leptin promotes melanoma tumor growth in mice related to increasing circulating endothelial progenitor cells numbers and plasma NO production, Journal of experimental \& clinical cancer research : CR, 30 (2011) 21. [PubMed: 21338489]

[121]. Rouaud F, Romero-Perez M, Wang H, Lobysheva I, Ramassamy B, Henry E, Tauc P, Giacchero D, Boucher JL, Deprez E, Rocchi S, Slama-Schwok A, Regulation of NADPH-dependent Nitric Oxide and reactive oxygen species signalling in endothelial and melanoma cells by a photoactive NADPH analogue, Oncotarget, 5 (2014) 10650-10664. [PubMed: 25296975]

[122]. Wang B, Xiong Q, Shi Q, Tan D, Le X, Xie K, Genetic disruption of host nitric oxide synthase II gene impairs melanoma-induced angiogenesis and suppresses pleural effusion, International journal of cancer. Journal international du cancer, 91 (2001) 607-611. [PubMed: 11267968]

[123]. Konopka TE, Barker JE, Bamford TL, Guida E, Anderson RL, Stewart AG, Nitric oxide synthase II gene disruption: implications for tumor growth and vascular endothelial growth factor production, Cancer Res, 61 (2001) 3182-3187. [PubMed: 11306506]

[124]. Zhang X, Fang X, Gao Z, Chen W, Tao F, Cai P, Yuan H, Shu Y, Xu Q, Sun Y, Gu Y, Axitinib, a selective inhibitor of vascular endothelial growth factor receptor, exerts an anticancer effect in melanoma through promoting antitumor immunity, Anti-cancer drugs, 25 (2014) 204-211. [PubMed: 24135499]

[125]. Thejass P, Kuttan G, Allyl isothiocyanate (AITC) and phenyl isothiocyanate (PITC) inhibit tumour-specific angiogenesis by downregulating nitric oxide (NO) and tumour necrosis factoralpha (TNF-alpha) production, Nitric Oxide, 16 (2007) 247-257. [PubMed: 17097904]

[126]. Guruvayoorappan C, Kuttan G, (+)-Catechin inhibits tumour angiogenesis and regulates the production of nitric oxide and TNF-alpha in LPS-stimulated macrophages, Innate immunity, 14 (2008) 160-174. [PubMed: 18562575]

[127]. Tao J, Tu YT, Li JW, Feng AP, Huang CZ, Wu Y, Shen GX, Endogenous production of nitric oxide contributes to proliferation effect of vascular endothelial growth factor-induced malignant melanoma cell, Clinical and experimental dermatology, 31 (2006) 94-99. [PubMed: 16309495]

[128]. Chen P, Huang Y, Bong R, Ding Y, Song N, Wang X, Song X, Luo Y, Tumor-associated macrophages promote angiogenesis and melanoma growth via adrenomedullin in a paracrine and autocrine manner, Clinical cancer research : an official journal of the American Association for Cancer Research, 17 (2011) 7230-7239. [PubMed: 21994414]

[129]. Lahdenranta J, Hagendoorn J, Padera TP, Hoshida T, Nelson G, Kashiwagi S, Jain RK, Fukumura D, Endothelial nitric oxide synthase mediates lymphangiogenesis and lymphatic metastasis, Cancer Res, 69 (2009) 2801-2808. [PubMed: 19318557]

[130]. Patenaude A, Fuller M, Chang L, Wong F, Paliouras G, Shaw R, Kyle AH, Umlandt P, Baker JH, Diaz E, Tong J, Minchinton AI, Karsan A, Endothelial-specific Notch blockade inhibits vascular function and tumor growth through an eNOS-dependent mechanism, Cancer Res, 74 (2014) 2402-2411. [PubMed: 24599126]

[131]. Ekmekcioglu S, Ellerhorst J, Smid CM, Prieto VG, Munsell M, Buzaid AC, Grimm EA, Inducible nitric oxide synthase and nitrotyrosine in human metastatic melanoma tumors correlate with poor survival, Clinical cancer research : an official journal of the American Association for Cancer Research, 6 (2000) 4768-4775.

[132]. Ekmekcioglu S, Ellerhorst JA, Prieto VG, Johnson MM, Broemeling LD, Grimm EA, Tumor iNOS predicts poor survival for stage III melanoma patients, International journal of cancer. Journal international du cancer, 119 (2006) 861-866. [PubMed: 16557582]

[133]. Ekmekcioglu S, Davies MA, Tanese K, Roszik J, Shin-Sim M, Bassett RL, Milton DR, Woodman SE, Prieto VG, Gershenwald JE, Morton DL, Hoon DS, Grimm EA, Inflammatory 
Marker Testing Identifies CD74 Expression in Melanoma Tumor Cells, and Its Expression Associates with Favorable Survival for Stage III Melanoma, Clinical cancer research : an official journal of the American Association for Cancer Research, (2016).

[134]. Johansson CC, Egyhazi S, Masucci G, Harlin H, Mougiakakos D, Poschke I, Nilsson B, Garberg L, Tuominen R, Linden D, Stolt MF, Hansson J, Kiessling R, Prognostic significance of tumor iNOS and COX-2 in stage III malignant cutaneous melanoma, Cancer Immunol Immunother, 58 (2009) 1085-1094. [PubMed: 19039588]

[135]. Tschugguel W, Pustelnik T, Lass H, Mildner M, Weninger W, Schneeberger C, Jansen B, Tschachler E, Waldhor T, Huber JC, Pehamberger H, Inducible nitric oxide synthase (iNOS) expression may predict distant metastasis in human melanoma, British journal of cancer, 79 (1999) 1609-1612. [PubMed: 10188914]

[136]. Gebhardt C, Sevko A, Jiang H, Lichtenberger R, Reith M, Tarnanidis K, Holland-Letz T, Umansky L, Beckhove P, Sucker A, Schadendorf D, Utikal J, Umansky V, Myeloid Cells and Related Chronic Inflammatory Factors as Novel Predictive Markers in Melanoma Treatment with Ipilimumab, Clinical cancer research : an official journal of the American Association for Cancer Research, (2015).

[137]. Fekkes D, Van Gool AR, Bannink M, Sleijfer S, Kruit WH, van der Holt B, Eggermont AM, Hengeveld MW, Stoter G, Nitric oxide production and monoamine oxidase activity in cancer patients during interferon-alpha therapy, Amino Acids, 37 (2009) 703-708. [PubMed: 18953681]

[138]. Li C, Hu Z, Liu Z, Wang LE, Gershenwald JE, Lee JE, Prieto VG, Duvic M, Grimm EA, Wei Q, Polymorphisms of the neuronal and inducible nitric oxide synthase genes and the risk of cutaneous melanoma: a case-control study, Cancer, 109 (2007) 1570-1578. [PubMed: 17328085]

[139]. Johansson CC, Mougiakakos D, Trocme E, All-Ericsson C, Economou MA, Larsson O, Seregard S, Kiessling R, Expression and prognostic significance of iNOS in uveal melanoma, International journal of cancer. Journal international du cancer, 126 (2010) 2682-2689. [PubMed: 19847812]

[140]. Lu T, Ramakrishnan R, Altiok S, Youn JI, Cheng P, Celis E, Pisarev V, Sherman S, Sporn MB, Gabrilovich D, Tumor-infiltrating myeloid cells induce tumor cell resistance to cytotoxic T cells in mice, The Journal of clinical investigation, 121 (2011) 4015-4029. [PubMed: 21911941]

[141]. Brash DE, UV-induced Melanin Chemiexcitation: A New Mode of Melanoma Pathogenesis, Toxicol Pathol, (2016).

[142]. Premi S, Brash DE, Chemical excitation of electrons: A dark path to melanoma, DNA Repair (Amst), 44 (2016) 169-177. [PubMed: 27262612]

[143]. Choi YJ, Uehara Y, Park JY, Chung KW, Ha YM, Kim JM, Song YM, Chun P, Park JW, Moon HR, Chung HY, Suppression of melanogenesis by a newly synthesized compound, MHY966 via the nitric oxide/protein kinase $\mathrm{G}$ signaling pathway in murine skin, Journal of dermatological science, 68 (2012) 164-171. [PubMed: 23088959]

[144]. Oba-Shinjo SM, Correa M, Ricca TI, Molognoni F, Pinhal MA, Neves IA, Marie SK, Sampaio LO, Nader HB, Chammas R, Jasiulionis MG, Melanocyte transformation associated with substrate adhesion impediment, Neoplasia, 8 (2006) 231-241. [PubMed: 16611417]

[145]. Melo FH, Molognoni F, Morais AS, Toricelli M, Mouro MG, Higa EM, Lopes JD, Jasiulionis MG, Endothelial nitric oxide synthase uncoupling as a key mediator of melanocyte malignant transformation associated with sustained stress conditions, Free Radic Biol Med, 50 (2011) 1263-1273. [PubMed: 21362470]

[146]. Kim SH, Hashimoto Y, Cho SN, Roszik J, Milton DR, Dal F, Kim SF, Menter DG, Yang P, Ekmekcioglu S, Grimm EA, Microsomal PGE2 synthase-1 regulates melanoma cell survival and associates with melanoma disease progression, Pigment Cell Melanoma Res, 29 (2016) 297-308. [PubMed: 26801201]

[147]. Wright F, Weller RB, Risks and benefits of UV radiation in older people: More of a friend than a foe?, Maturitas, 81 (2015) 425-431. [PubMed: 26049767] 


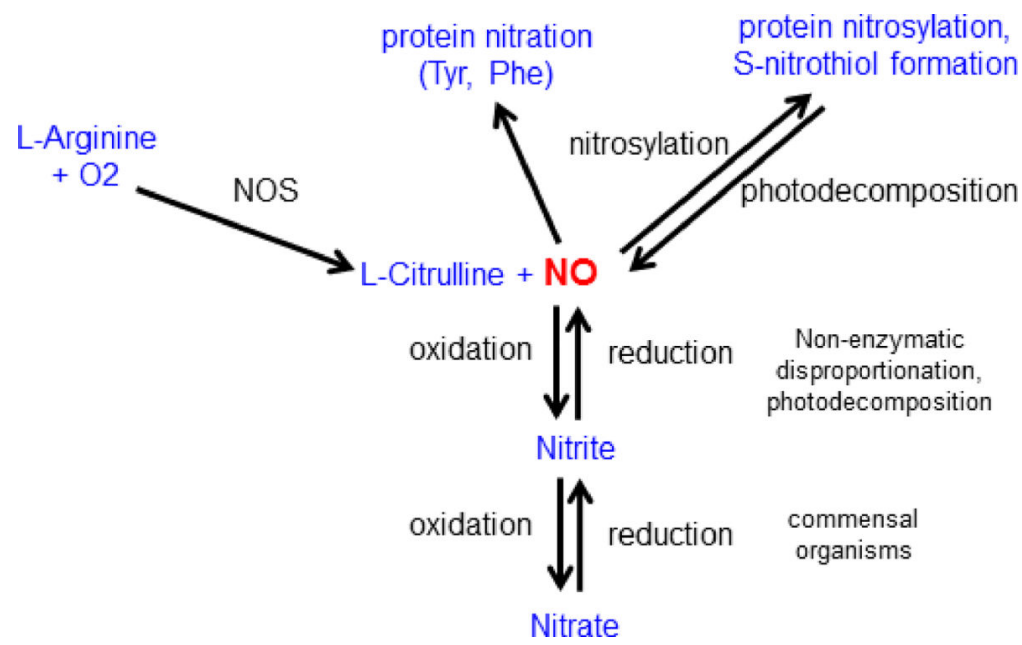

Figure 1. NO biochemistry.

NO is produced by various biochemical processes and is involved in posttranslational modifications of proteins. 


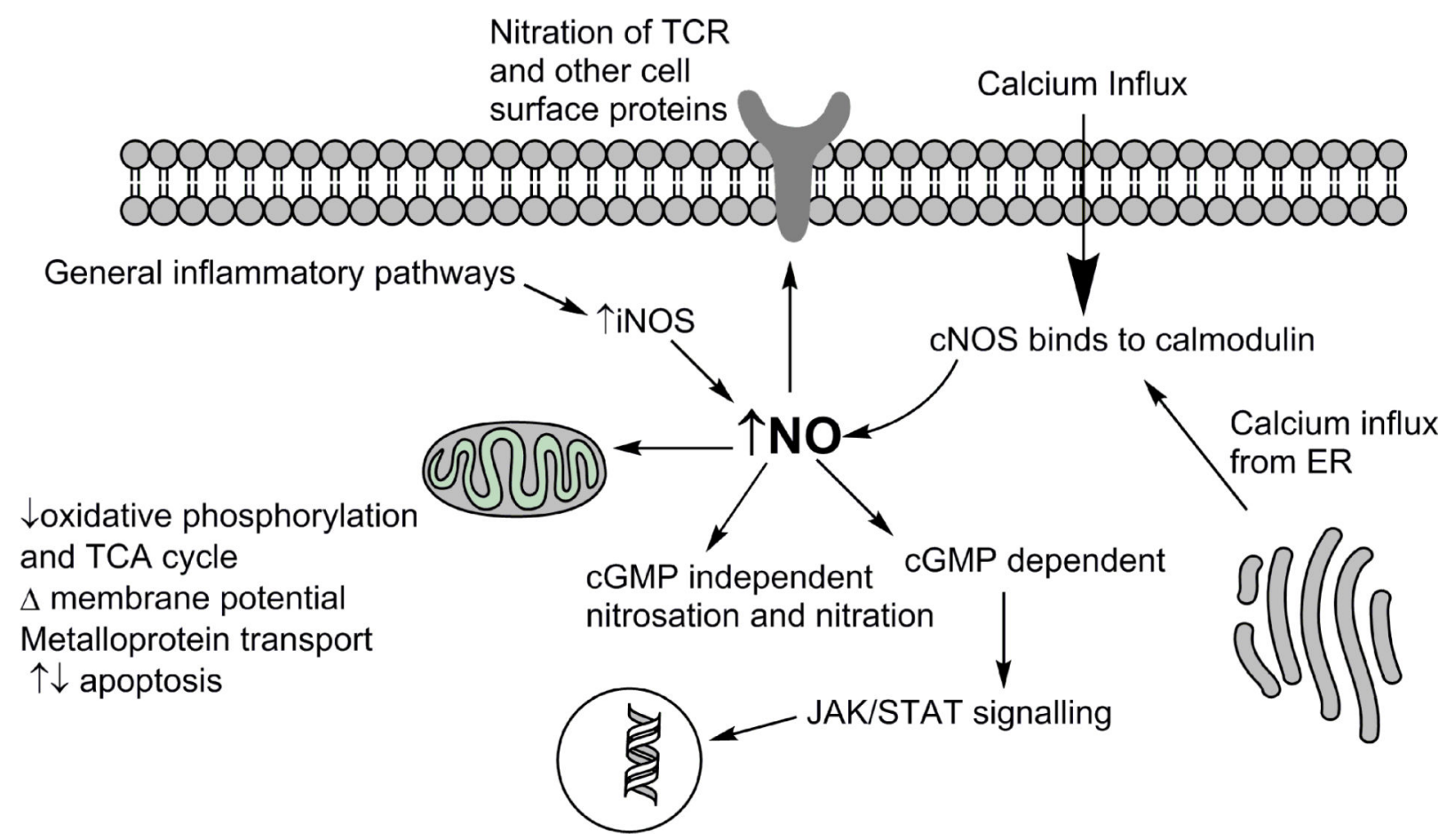

Figure 2. NO general cellular function.

NO is involved in cGMP dependent and independent cell processes. It is involved in regulating mitochondrial function, apoptotic processes and multiple other pathways such interferon response pathways and production of chemokines/cytokines. This figure has been generated utilizing the tools provided in the ChemDraw program (PerkinElmer, Waltham, MA, USA). 


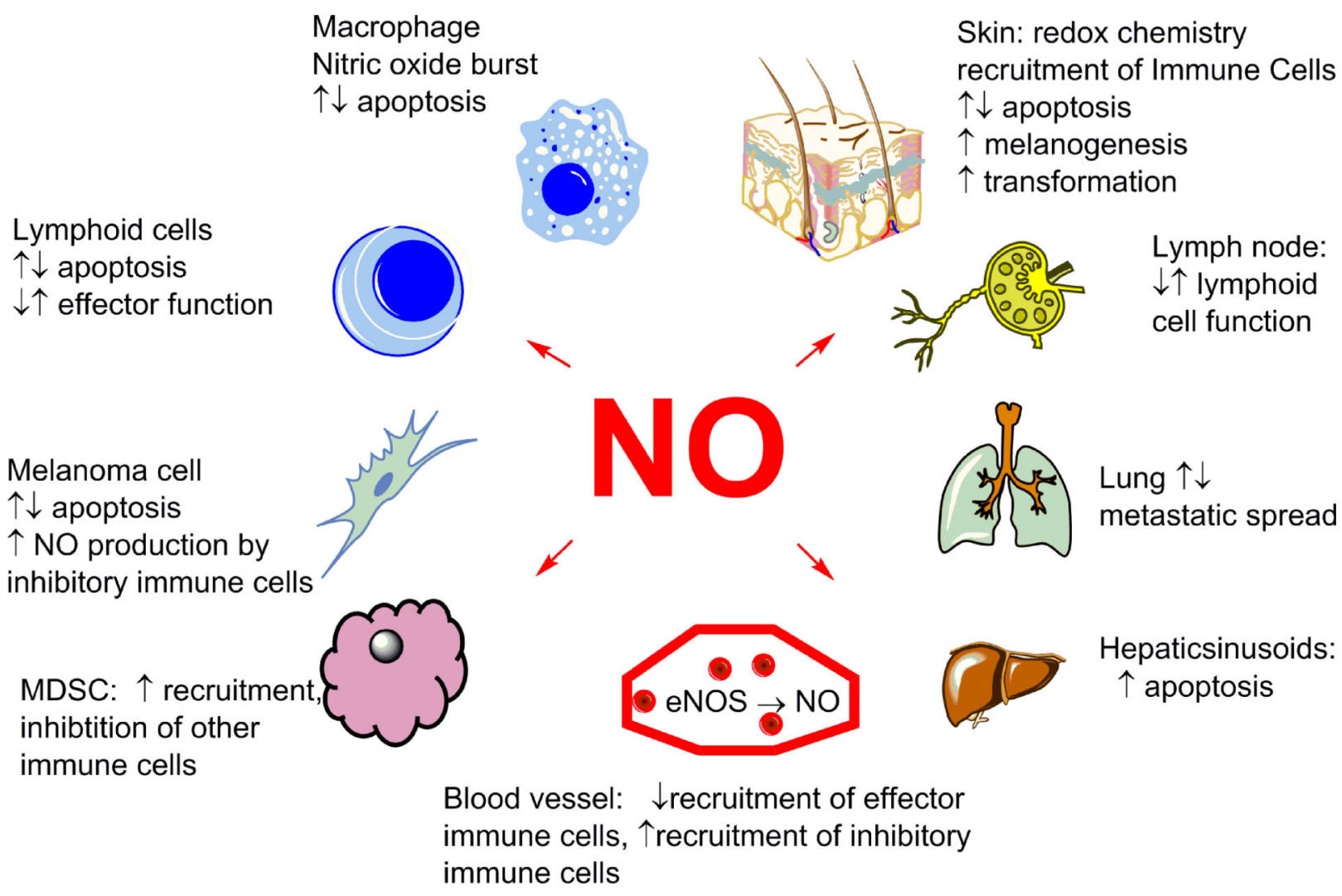

Figure 3. Physiologic roles of NO.

$\mathrm{NO}$ is important in regulating the activities of immune cells, metastatic spread to organs such as lung and liver, and the metabolic activity of melanoma cells themselves. This figure has been generated utilizing the tools provided in the ChemDraw program (PerkinElmer, Waltham, MA, USA). 